\title{
Effect of Using Dried Distiller Grains with Soluble (Ddgs) as a New Protein Source on Meat and Milk Production and their Qualities:
}

1- Using Dried Distiller Grains with Soluble (DDGS) Instead of Cotton Seed Cake or Soybean Meal Cake in Rations of Lactating Friesian Cows

Etman, K. E. I.; T. I. El Monayer; S. K. Sayed; F. A. El - Sayed and A. H. Ghoniem

Animal Production Research Institute, Agriculture Research Center, Ministry of Agriculture, Cairo, Egypt

\section{ABSTRACT}

Twenty four Friesian cows at $2^{\text {nd }}$ lactating season with average live body weight (LBW) $383 \mathrm{Kg}$. Animals were randomly distributed into four similar groups (6 animal each), to be fed concentrate feed mixture (CFM) containing cotton seed cake or soybean meal or DDGS as a source of protein in rations B, C and D, respectively compared to that containing each of them in ration A as a control ration.Feeding trial lasted about 210 days and animals fed CFM, berseem hay and rice straw with rate of 60,25 and $15 \%$ respectively. These proportions were chosen to achieve approximately isonitrogenous rations containing a bout $13 \% \mathrm{CP}$. The results obtained showed that digestibility coefficient of OM,CP,EE and NFE for ration D (containing DDGS) showed significant $(\mathrm{P}<0.05)$ higher than the others, while differences in $\mathrm{DM}$ and $\mathrm{CF}$ digestibility were higher significant $(\mathrm{P}<0.05)$ with feeding on ration $\mathrm{C}$ than $\mathrm{A}$ or $\mathrm{B}$ but without significant effect with ration D. Feeding values for ration D expressed as TDN (\%), DCP (\%), DE and ME (M cal / Kg $\mathrm{DM})$ were significant $(\mathrm{P}<0.05)$ higher than the other rations. Ration D containing DDGS tended to significant $(\mathrm{P}<0.05)$ increased for both actual milk $(9.028 \mathrm{~kg})$ and $4 \%$ FCM yield $(8.906 \mathrm{~kg})$ and improved milk composition and their yields than rations A and B. Feed efficiency as $\mathrm{kg} \mathrm{DM} / \mathrm{Kg}$ actual milk or $\mathrm{kg} 4 \% \mathrm{FCM}$ yields was the best with ration D, than the other rations. Ration D showed the cheapest feed cost to get one $\mathrm{kg}$ actual milk (2.072 LE) or $\mathrm{kg} \mathrm{4 \%} \mathrm{FCM} \mathrm{yield}(2.100 \mathrm{LE})$. Also, ration D gave the highest net revenue (35.464 LE) and economical efficiency (1.90). The mean values of the $\mathrm{NH}_{3}-\mathrm{N}$, Total $-\mathrm{N}$ and NPN $(\mathrm{mg} / 100 \mathrm{ml})$ concentrations were significant $(\mathrm{P}<0.05)$ higher by feeding on ration D. Blood parameters showed that there were no adverse effects, however these parameters were within the normal values.

Keyword: DDGS, digestibility coefficients, feeding values, milk production, economic efficiency, and blood and rumen parameters

\section{INTRODUCTION}

The big problems in animal production projects are the shortage of feed stuff especially the sources of protein. Because of little and decrease of protein sources and higher its price, some other attempts were done to solve this problem by improve feedstuff and increase their feeding values (Etman et al., 2011; Arelovich et al., 2000; Bremer et al., 2005; El-Sayed et al., 2002; Faichney and White, 1977).

Dried distiller grains with soluble (DDGS) are the most by -product for fermentation and it is the important sources of protein for feeding meat or milk animals. DDGS is a co-product of ethanol industry which contains more energy and protein (Etman et al., 2010). This product have been used in many trials as a source of energy or protein in rations formulation of dairy animals, beef steers, heifers, sheep, poultry and swine(May et al., 2009; Leupp et al., 2009 and Reed et al., 2006). In this respect, Etman et al. (2011) showed that the use of DDGS with rate $27 \%$ in rations of fattening buffalo calves tended to higher digestibility with better performance of fattening animals. Also, Etman et al. (2014) reported higher daily gain of growing lambs with using 30\% DDGS in rations of sheep.

The objective of this work was to study the effect of using DDGS as a source of protein in rations formulation of lactating Friesian cows on digestibility, feeding values, milk yield and economical efficiency.

\section{MATERIALS AND METHODS}

Twenty-four cows averaging $383 \mathrm{~kg}$ live body weight and at the $2^{\text {nd }}$ lactation season were chosen and divided into four similar groups (6 in each). The trial was conducted at the Animal House belonging to Animal Production Research Institute and El-Ma'dway station at Masr - Alexandria desert road, Egypt. All animals were randomly assigned to receive four experimental rations. The experimental rations contained concentrated feed mature (CFM), berseem hay and rice straw with rate of 60 , 25 and $15 \%$, respectively.

Cotton seed cake, soybean and dried distiller grain were contributed together to get $50 \%$ as protein of CFM for ration $\mathrm{A}$, while the $50 \%$ protein content of CFM for rations $\mathrm{B}, \mathrm{C}$ and $\mathrm{D}$ were come from cotton seed cake or soybean meal or dried distiller grains, respectively.

All animals were received experimental rations according to NRC (1989). Daily allowance from CFM and roughages were adjusted every two weeks based on milk production and body weight changes. All animals were milked twice daily at 8.00 a.m. and 4.00 p.m. Milk yield were individually recorded and converted to $4 \%$ fat corrected yield according to Gaines (1923).Representative samples of milk yield were prepared to make composite milk sample for analyses.

At the middle period of feeding trial, four digestibility trails using three cows chosen randomly from each group to determine the digestibility coefficients and feeding values of experimental rationS using Acid Insoluble Ash (AIA) procedure as a natural marker according to Van Keulen and Young (1977). Each digestibility trail consisted of 7 days collection period . Feces were collected for each animal to prepare individual feces samples for analysis. Rumen liquor samples were also taken from the same three animals of each group at $3 \mathrm{hr}$. post feeding, during 3 successive days, using stomach tube. samples were filtered through two layers of surgical gauze and preserved for determine some measured. Rumen $\mathrm{pH}$ was immediately measured using digital $\mathrm{pH}$ meter. At the same time, blood samples were taken from the jugular vein of the animals belonging to the digestibility trial at $3 \mathrm{hr}$. after feeding. Blood serum was preserved to measure some blood parameters. 


\section{Analysis procedures:}

Representative samples of feeds, feces and refused from feeds were analyzed to determine DM, CP, EE, CF and ash contents according to A.O.A.C (2000).

Composite milk samples were analyzed for fat, protein and total solid by milk- scan model 133B, while lactose was determined by differences. The filtered rumen liquors were analyzed to determine total Nitrogen (TN), protein nitrogen $(\mathrm{PN})$ and ammonia-nitrogen $(\mathrm{NH} 3-\mathrm{N})$ according to AOAC (2000), while total volatile fatty acids (VFA's) concentration were determined according to Eadie et al. (1976). Blood serum was separated from the whole blood to determine the total protein, albumin, transaminase activities and creatinine and urea $-\mathrm{N}$ using commercial kits of Bio-Merieus, lab, France.

Data were statistically analyzed as one way analysis of variance using general linear model (GLM) program of SAS (1996) according to the following model:

where:

$$
\mathbf{Y i j}=\boldsymbol{\mu}+\mathbf{T i}+\mathbf{e i j}
$$

Yij $=$ the observation

$\boldsymbol{\mu}=$ Over all means

$\mathrm{T} i=$ effect of treatment

eij $=$ experimental error

The significant differences among means were tested using Duncan Multiple range test (Duncan, 1955).

\section{RESULTS AND DISCUSSION}

Data in Table (1) showed different ingredients of concentrate feed mixture (CFM) of experimental rations. The CFM of ration A contains cotton seed cake, soybean meal and DDGS as a source of $50 \%$ protein, while the previous successive ingredients were contributed with 50\% as protein of CFM for rations $\mathrm{B}, \mathrm{C}$ and $\mathrm{D}$, respectively. In addition, all CFM for all experimental rations were almost equal in DM, CP and OM\% as shown in Table (2), while $\mathrm{EE}, \mathrm{CF}, \mathrm{NFE}$ and ash contents had some little variation. On the other hand, chemical composition of berseem hay, rice straw, cotton seed cake, soybean and dried distiller grains with soluble (DDGS) were illustrated in Table (2). They were nearly similar analysis as mentioned by Etman et al. (2014). It could be noticed that, the DDGS had nearly equal CP with cotton seed cake, but it had higher EE and lower CF \% than those of cotton seed cake.

Table 1. Ingredients of concentrate feed mixture (CFM) containing different sources of protein for experimental rations.

\begin{tabular}{lcccc}
\hline \multirow{2}{*}{ Items } & \multicolumn{4}{c}{ CFM of experimental rations } \\
\cline { 2 - 5 } & A & B & C & D \\
\hline Ingredients (\%): & 29 & 26 & 26 & 21 \\
Yellow corn & 8.85 & 27 & - & - \\
Cotton seed cake & 5.23 & - & 16 & - \\
Soybean meal & 8.52 & - & - & 26 \\
Dried distiller grains & 15.40 & 22 & 5 & 20 \\
(DDGS) & 15 & 10 & 35 & 15 \\
Wheat bran & 15 & 10 & 15 & 15 \\
Rice bran & - & 2 & - & - \\
Molasses & 2 & 2 & 2 & 2 \\
Protected fat & 1 & 1 & 1 & 1 \\
Limestone & 100 & 100 & 100 & 100 \\
Salt & & & & \\
\hline \multicolumn{2}{r}{} &
\end{tabular}

Table 2. Chemical composition of ingredients and concentrate feed mixtures.

\begin{tabular}{|c|c|c|c|c|c|c|c|}
\hline \multirow{2}{*}{ Items } & \multirow{2}{*}{ DM\% } & \multicolumn{5}{|c|}{ Chemical composition on DM basis (\%) } & \multirow{2}{*}{ OM\% } \\
\hline & & $\mathbf{C P}$ & EE & CF & NFE & Ash & \\
\hline Berseem hay (BH) & 90.65 & 15.40 & 3.12 & 24.54 & 47.14 & 9.80 & 90.20 \\
\hline Rice straw (RS) & 91.52 & 3.08 & 1.64 & 44.25 & 39.08 & 11.95 & 88.05 \\
\hline Cotton seed cake (CSK) & 90.14 & 26.00 & 1.43 & 24.12 & 42.61 & 5.84 & 94.16 \\
\hline Soybean meal (SB) & 88.16 & 44.02 & 1.45 & 7.86 & 39.75 & 6.92 & 93.08 \\
\hline Dried distiller grain (DDGS) & 89.75 & 27.10 & 8.04 & 8.15 & 49.28 & 7.43 & 92.57 \\
\hline \multicolumn{8}{|c|}{ * Concentrate feed mixture (CFM )of: } \\
\hline CFM (A) & 90.81 & 14.15 & 4.73 & 7.35 & 65.03 & 8.74 & 91.26 \\
\hline CFM (B) & 91.76 & 14.24 & 5.26 & 8.64 & 63.84 & 8.02 & 91.98 \\
\hline CFM (C) & 91.12 & 14.50 & 6.24 & 6.38 & 63.04 & 9.84 & 90.16 \\
\hline CFM (D) & 91.68 & 14.25 & 5.85 & 6.63 & 63.93 & 9.34 & 90.66 \\
\hline
\end{tabular}

* CFM of ration (A) containing, cotton seed cake, soybean and DDGS as a source of protein which contributed together to get $50 \%$ crude protein , while cotton seed cake, soybean and DDGS of ration B, C and D, respectively contributed with $50 \%$ as source of crude protein.

Average daily feed intake and calculated composition of experimental rations:

Table (3) revealed that the total DM intake with four successive groups were nearly equal, recording $11.400,11.542,11.520$ and $11.471 \mathrm{~kg} \mathrm{DM} /$ day/ head with rations $\mathrm{A}, \mathrm{B}, \mathrm{C}$ and $\mathrm{D}$, respectively.

On the other hand, the calculated composition of experimental rations were almost equal in all nutrients, indicating some little increase in $\mathrm{CF} \%$ of rations $\mathrm{A}$ and $\mathrm{B}$ (17.19 and $17.96 \%$ ) versus 16.61 and 16.76 for rations $C$ and $\mathrm{D}$, respectively. However, all experimental rations were isonitrogenous and isocaloric, as shown in Table (3).

The results also revealed that the digestibility coefficients of $\mathrm{OM}, \mathrm{CP}, \mathrm{EE}$ and $\mathrm{EE}$ of ration $\mathrm{D}$ were significantly $(\mathrm{P}<0.05)$ higher than those of other $\mathrm{C}$ and $\mathrm{D}$ were significantly $(\mathrm{P}<0.05)$ higher than those of others. The differences among rations $\mathrm{A}, \mathrm{B}$ and $\mathrm{C}$ in the most of nutrients digestibility were not significant, but digestibility coefficients of $\mathrm{DM}$ and $\mathrm{CF}$ for ration $\mathrm{C}$ were significant $(\mathrm{P}<0.05)$ higher than those of rations $\mathrm{A}$ and $\mathrm{B}$ (Table 3 ). Generally, the ration D (containing DDGS) appeared the highest $(\mathrm{P}<0.05)$ significant of most nutrients. It might be due to higher $\mathrm{CF}$ fractionation of ration $\mathrm{D}$ such as ADF and NDF as reported by Etman et al. (2014). They found that the NDF was $46 \%$ for DDGS versus 40 and $15 \%$ for undecorticated cotton seed cake and soybean meal, respectively. Also, increase in digestibility coefficients of most nutrients for ration $\mathrm{D}$ were found with increasing DDGS levels in CFM of ration as a source of protein (Etman et al., 2014a). 
The results presented in Table (3) showed feeding values as TDN (\%), DCP(\%)(\%), DE (Mcal/ Kg DM) and $\mathrm{ME}(\mathrm{Mcal} / \mathrm{Kg} \mathrm{DM})$ for different experimental rations. The nutritive value as TDN and DCP (\%) were significantly $(\mathrm{P}<0.05)$ higher for ration $\mathrm{D}$ compared with the other rations. Also, DE (Mcal / Kg DM) and I (Mcal / Kg DM) of ration $\mathrm{d}$ take the same previous trend. Increasing feeding values as TDN or DCP for rations D might be due to higher digestibility of most their nutrients. Results of TDN, DCP and DE for ration $\mathrm{C}$ were agreement with those reported by Walter et al. (2012) and Etman et al. (2014). They reported that using DDGS as a source of protein caused higher nutrients digestibility. The feeding value of ration D expressed as TDN, DCP and DE were similar with those recorded by Etman et al. (2014) and ElMonayer (2015). Moreover, Etman et al. (2010\& 2011) concluded that increasing and improving in digestibility coefficients and nutritive values of ration containing DDGS might be attributed to higher availability of the nutrient contents of DDGS as reported by Leupp et al. (2009). Generally, ration D (containing DDGS) appeared to higher digestibility and feeding values than other rations.

Table 3. Average daily feed intake, composition, digestibility coefficients and nutritive values of different experimental rations by lactating Friesian cows.

\begin{tabular}{|c|c|c|c|c|}
\hline \multirow{2}{*}{ Items } & \multicolumn{4}{|c|}{ Experimental rations } \\
\hline & A & B & $\mathbf{C}$ & D \\
\hline \multicolumn{5}{|l|}{$\begin{array}{l}\text { Av. daily feed intake } \\
(\mathrm{Kg} \text { DM/h): }\end{array}$} \\
\hline $\begin{array}{ll}\text { Concentrate } & \text { feed } \\
\text { mixture }(\mathrm{CFM}) & \end{array}$ & 6.840 & 6.930 & 6.912 & 6.882 \\
\hline Berseem hay (CFM) & 2.850 & 2.880 & 2.880 & 2.868 \\
\hline Rice straw (RS) & 1.710 & 1.732 & 1.728 & 1.721 \\
\hline Total DM intake & 11.400 & 11.540 & 11.520 & 11.471 \\
\hline \multicolumn{5}{|c|}{ Composition of experimental rations (\%DM basis): } \\
\hline $\mathrm{DM}$ & 90.88 & 91.45 & 91.06 & 91.40 \\
\hline OM & 90.52 & 90.95 & 89.86 & 90.16 \\
\hline $\mathrm{CP}$ & 12.80 & 12.85 & 13.01 & 12.86 \\
\hline $\mathrm{EE}$ & 3.76 & 4.19 & 4.77 & 4.54 \\
\hline $\mathrm{CF}$ & 17.19 & 17.96 & 16.61 & 16.76 \\
\hline NFE & 56.77 & 55.95 & 55.47 & 56.00 \\
\hline Ash & 9.48 & 9.05 & 10.14 & 9.84 \\
\hline
\end{tabular}

Digestibility coefficients of experimental rations (\%):

\begin{tabular}{lllll} 
DM & $85.44^{\mathrm{b}}$ & $86.92^{\mathrm{b}}$ & $88.63^{\mathrm{a}}$ & $89.15^{\mathrm{a}}$ \\
OM & $90.06^{\mathrm{b}}$ & $91.20^{\mathrm{b}}$ & $92.39^{\mathrm{b}}$ & $95.14^{\mathrm{a}}$ \\
CP & $65.50^{\mathrm{b}}$ & $64.75^{\mathrm{b}}$ & $67.82^{\mathrm{b}}$ & $70.94^{\mathrm{a}}$ \\
EE & $69.42^{\mathrm{b}}$ & $70.12^{\mathrm{b}}$ & $70.04^{\mathrm{b}}$ & $74.15^{\mathrm{a}}$ \\
CF & $58.86^{\mathrm{b}}$ & $60.81^{\mathrm{b}}$ & $62.12^{\mathrm{a}}$ & $63.26^{\mathrm{a}}$ \\
NFE & $70.38^{\mathrm{b}}$ & $69.73^{\mathrm{b}}$ & $70.14^{\mathrm{b}}$ & $72.50^{\mathrm{a}}$ \\
\hline
\end{tabular}

Feeding values:

$\begin{array}{lllll}\text { TDN }(\%) & 64.32^{\mathrm{c}} & 64.87^{\mathrm{c}} & 65.57^{\mathrm{b}} & 67.90^{\mathrm{a}}\end{array}$

$\begin{array}{lllll}\text { DCP (\%) } & 8.38^{\mathrm{c}} & 8.32^{\mathrm{c}} & 8.82^{\mathrm{b}} & 9.12^{\mathrm{a}}\end{array}$

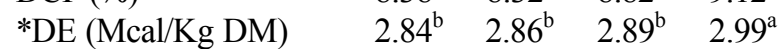

\begin{tabular}{lllll}
$* \mathrm{ME}(\mathrm{Mcal} / \mathrm{Kg} \mathrm{DM})$ & $2.32^{\mathrm{b}}$ & $2.34^{\mathrm{b}}$ & $2.35^{\mathrm{b}}$ & $2.44^{\mathrm{a}}$ \\
\hline
\end{tabular}

* DE was calculated according to Church and Pond (1982).

$* \mathrm{ME}=\mathrm{DE} * 0.82 \quad$ (NRC,2001).

a, $b$ and c: Means in the same row with different superscripts are significantly $(\mathbf{P}<0.05)$ different
Actual, fat corrected milk (FCM) yields and its composition:

The results obtained in Table (4) showed that the actual milk yield significant $(\mathrm{P}<0.05)$ increased with animals fed rations $\mathrm{C}$ and $\mathrm{D}$ compared with those fed rations $\mathrm{A}$ and $\mathrm{B}$. The same previous trend was observed with $4 \%$ fat corrected milk (4\% FCM) yield. It could be noticed that, concentrate feed mixture containing DDGS (ration D) tended to higher both actual and 4\% FCM yields than the others owing to improve digestibility coefficients and increase feeding values of these ration.

Table 4. Average daily actual, $4 \%$ fat corrected milk (FCM) yields and its composition for lactating Friesian cows fed different experimental rations.

\begin{tabular}{|c|c|c|c|c|c|}
\hline \multirow{2}{*}{ Items } & & \multicolumn{4}{|c|}{ Experimental rations } \\
\hline & & A & B & C & D \\
\hline \multicolumn{6}{|c|}{ Av. milk production ( $\mathrm{Kg} / \mathrm{head} /$ day): } \\
\hline Actual milk yield & & $8.260^{\mathrm{c}}$ & $8.504^{b}$ & $8.845^{\mathrm{a}}$ & $9.028^{\mathrm{a}}$ \\
\hline \multicolumn{6}{|c|}{ Av. milk composition (\%) and its yield (gm/ cow/day): } \\
\hline Fat & $(\%)$ & $3.75^{\mathrm{b}}$ & $3.82^{\mathrm{b}}$ & $3.95^{\mathrm{a}}$ & $3.91^{\mathrm{a}}$ \\
\hline *4\% FCM yield & & $7.954^{\mathrm{c}}$ & $8.277^{\mathrm{b}}$ & $8.773^{\mathrm{a}}$ & $8.906^{\mathrm{a}}$ \\
\hline Fat yield & (gm) & $310^{\mathrm{b}}$ & $325^{\mathrm{b}}$ & $349^{\mathrm{a}}$ & $353^{\mathrm{a}}$ \\
\hline Protein & $(\%)$ & $3.27^{\mathrm{b}}$ & $3.30^{\mathrm{b}}$ & $3.36^{\mathrm{a}}$ & $3.34^{\mathrm{a}}$ \\
\hline Protein yield & (gm) & $270^{\mathrm{b}}$ & $281^{\mathrm{b}}$ & $297^{\mathrm{a}}$ & $302^{\mathrm{a}}$ \\
\hline Lactose & $(\%)$ & $4.65^{\mathrm{b}}$ & $4.82^{\mathrm{b}}$ & $4.95^{\mathrm{b}}$ & $5.44^{\mathrm{a}}$ \\
\hline Lactose yield & (gm) & $384^{\mathrm{c}}$ & $410^{\mathrm{bc}}$ & $438^{\mathrm{b}}$ & $491^{\mathrm{a}}$ \\
\hline **TS & $(\%)$ & $12.87^{\mathrm{c}}$ & $13.15^{\mathrm{b}}$ & $13.58^{\mathrm{b}}$ & 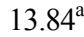 \\
\hline TS yield & (gm) & $1063^{\mathrm{b}}$ & $1118^{\mathrm{b}}$ & $1201^{\mathrm{a}}$ & $1249^{\mathrm{a}}$ \\
\hline ***SNF & $(\%)$ & $9.12^{\mathrm{c}}$ & $9.33^{\mathrm{c}}$ & $9.63^{\mathrm{b}}$ & $9.93^{\mathrm{a}}$ \\
\hline SNF yield & (gm) & $753^{\mathrm{b}}$ & $793^{\mathrm{b}}$ & $852^{\mathrm{a}}$ & $896^{\mathrm{a}}$ \\
\hline
\end{tabular}

Data presented in Table (4) revealed that all milk composition as fat and protein (\%) of animals fed rations D and $\mathrm{C}$ showed the highest $(\mathrm{P}<0.05)$ values than others. While others milk contents (lactose, T.S and SNF \%) increased $(\mathrm{P}<0.05)$ with animals fed ration $\mathrm{D}$ than others. The fat ,protein T.S and SNF yields of animals fed rations $\mathrm{C}$ and $\mathrm{D}$ showed the highest $(\mathrm{P}<0.05)$ values than others. While lactose yield increased $(\mathrm{P}<0.05)$ with animals fed ration $\mathrm{D}$ than others.

From the previous data, it could be seen that animals fed ration $\mathrm{C}$ (containing $\mathrm{SBM}$ ) and ration D (containing DDGS) had significantly $(\mathrm{P}<0.05)$ higher of most milk composition and their yields (Table 4). It could be noticed that using cotton seed cake, soybean meal or DDGS as a source of protein in ration of lactating Friesian cows tended to higher milk yield and its composition. These results were in agreement with those reported by Etman et al. (2012) who found that actual and 4\% FCM yields increased with increasing dried distiller grains with soluble as a source of protein in rations of lactating Friesian cows. On the other hand, Anderson et al. (2006), Janicek et al. (2008), Kelzer et al. (2009) and Zhang et al. (2010) showed higher milk yield with increasing DDGS levels in rations of lactating cows. Also, it could be noticed that increasing of milk yield and its composition of animals fed ration D (containing DDGS) might be due to higher in fermented NDF of DDGS than the other rations as reported by Etman et al. (2014). 
Average daily feed conversion rate and feed efficiency of experimental rations:

Data presented in Table (5) showed that the DM intake $(\mathrm{kg} / \mathrm{h} / \mathrm{d})$ wase almost equal in different experimental groups, showing somewhat higher with groups fed CFM containing cotton seed cake $(11.542 \mathrm{~kg} / \mathrm{h} / \mathrm{d})$ and soybean meal $(11.520 \mathrm{~kg} / \mathrm{h} / \mathrm{d})$. However, the TDN intake showed the highest value with group fed ration containing DDGS $(7.789 \mathrm{~kg} / \mathrm{h})$. At the same time, DCP intake appeared the same higher previous trend as TDN intake. Increasing feed intake of animals fed ration containing DDGS (ration D) might be attributed not only higher digestibility coefficients of all nutrients of these ration, but also higher it's feeding values such as TDN, DCP, DE and ME (table 3). These results were agreement with those reported by Etman et al. (2011\& 2014) and El-Shinnawy et al. (2015).

The feed efficiency was calculated as $\mathrm{kg}$ DM, TDN or DCP per $\mathrm{kg}$ actual milk yield or $\mathrm{kg} \mathrm{4 \%} \mathrm{FCM} \mathrm{yield,} \mathrm{as}$ shown in Table (5). It could be noticed that the difference in feed utilization efficiency in case of actual or 4\% FCM yields among different experimental rations were not significant. However, the animals fed ration D (containing DDGS) showed the most feed efficiency as amounts DM

or $1.288 \mathrm{~kg}$, respectively. On the other hand, feed Rice straw (RS)

utilization as $\mathrm{kg} \mathrm{TDN} / \mathrm{kg}$ actual or 4\% FCM yield found to

be most efficient for animals fed ration $\mathrm{C}$ (containing soybean meal) with no significant difference, while feed efficiency as $\mathrm{Kg} \mathrm{DCP} / \mathrm{Kg}$ actual or $4 \% \mathrm{FCM}$ yield was almost equal among different experimental groups without significant differences. Better feed efficiency with animals fed ration containing DDGS was reported by Etman et al. (2014) and El-Shinnawy et al. (2015).Generally, using
DDGS in rations tended to increase milk yield and improve feed utilization efficiency.

Table 5. Average daily feed conversion rate and feed efficiency for lactating cows fed the experimental rations.

\begin{tabular}{lcccc}
\hline \multirow{2}{*}{ Items } & \multicolumn{4}{c}{ Experimental rations } \\
& A & B & C & D \\
\hline No. animals & 6 & 6 & 6 & 6 \\
Av. LBW (Kg) & 380 & 385 & 382 & 384 \\
Experimental period (day) & 210 & 210 & 210 & 210 \\
\hline
\end{tabular}

Av. daily feed unit intake:

$\begin{array}{lllll}\mathrm{DM}(\mathrm{kg} / \mathrm{h} / \mathrm{d}) & 11.400 & 11.542 & 11.520 & 11.471\end{array}$

$\begin{array}{lllll}\mathrm{TDN}(\mathrm{kg} / \mathrm{h} / \mathrm{d}) & 7.332 & 7.492 & 7.554 & 7.789\end{array}$

DCP $(\mathrm{kg} / \mathrm{h} / \mathrm{d}) \quad \begin{array}{lllll}0.955 & 0.961 & 1.016 & 1.046\end{array}$

Av. actual milk yield (kg) $\quad 8.260^{\mathrm{c}} \quad 8.504^{\mathrm{b}} \quad 8.845^{\mathrm{a}} \quad 9.028^{\mathrm{a}}$

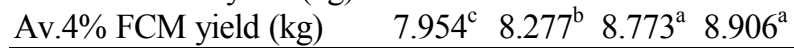

Feed efficiency with actual milk :

$\begin{array}{llllll}\mathrm{Kg} \mathrm{DM} / \mathrm{kg} \text { milk yield } & & 1.380 & 1.358 & 1.302 & 1.271\end{array}$

$\begin{array}{llllll}\mathrm{Kg} \text { TDN} / \mathrm{kg} \text { milk yield } & 0.888 & 0.881 & 0.845 & 0.863\end{array}$

\begin{tabular}{llllll}
$\mathrm{Kg}$ DCP$/ \mathrm{kg}$ milk yield & 0.116 & 0.113 & 0.115 & 0.116 \\
\hline
\end{tabular}

Feed efficiency with 4\% FCM:

$\mathrm{KgDM} / \mathrm{kg} 4 \%$ FCM yield $\quad 1.433 \quad 1.395 \quad 1.313 \quad 1.288$

$\mathrm{KgTDN} / \mathrm{kg} 4 \%$ FCM yield $\quad \begin{array}{lllll}0.922 & 0.905 & 0.861 & 0.875\end{array}$

$\mathrm{KgDCP} / \mathrm{kg} 4 \% \mathrm{FCM}$ yield $\quad 0.120 \quad 0.116 \quad 0.116 \quad 0.117$

a, $b$ and $c:$ Means in the same row with different superscripts are significantly $(\mathbf{P}<0.05)$ different.

\section{Feed cost and economic efficiency}

From data in Table (6) It could be noticed that the cheapest cost of feed intake per head was recorded with ration $\mathrm{D}(18.704 \mathrm{LE} / \mathrm{h})$. The same previous trend was observed with feed cost/ $\mathrm{kg}$ milk or 4\% FCM yields, recording 2.072 and 2.100 LE respectively. Moreover, the highest net revenue and net revenue/ $\mathrm{kg} \mathrm{4 \% FCM} \mathrm{yield} \mathrm{was}$ obtained with animals fed ration $\mathrm{D}$ than those fed other rations. At the same time, the best $(\mathrm{P}<0.05)$ net revenue per $\mathrm{kg}$ milk yield was observed with animal fed rations $\mathrm{C}$ and $\mathrm{D}$ than those fed other rations. Consequently, the experimental ration D (containing DDGS) appeared to the best economical efficiency (2.90) followed by ration $\mathrm{C}$ (2.76). The previous trend was reported by Etman et al. (2011\& 2014).

Table 6. Average feed cost and economical efficiency for lactating Friesian cows fed different experimental rations.

\begin{tabular}{|c|c|c|c|c|}
\hline \multirow{2}{*}{ Items } & \multicolumn{4}{|c|}{ Experimental rations } \\
\hline & $\mathbf{A}$ & B & C & D \\
\hline \multicolumn{5}{|c|}{ Av. daily feed ingredient intake, as fed (kg/ head): } \\
\hline $\begin{array}{l}\text { Concentrate feed mixture } \\
\text { (CFM) }\end{array}$ & 7.532 & 7.552 & 7.586 & 7.507 \\
\hline Berseem hay $(\mathrm{BH})$ & 3.144 & 3.186 & 3.177 & 3.164 \\
\hline Rice straw (RS) & 1.868 & 1.892 & 1.888 & 1.880 \\
\hline \multicolumn{5}{|c|}{ Av. daily milk yield (kg/head): } \\
\hline * Actual milk yield & $8.260^{\mathrm{c}}$ & $8.504^{\mathrm{b}}$ & $8.845^{\mathrm{a}}$ & $9.028^{\mathrm{a}}$ \\
\hline 4\% FCM yield & $7.954^{\mathrm{c}}$ & $8.277^{\mathrm{b}}$ & $8.773^{\mathrm{a}}$ & $8.906^{\mathrm{a}}$ \\
\hline \multicolumn{5}{|c|}{ **Feed cost and economical efficiency } \\
\hline Cost of feed intake & 19.259 & 20.959 & 19.227 & 18.704 \\
\hline
\end{tabular}

(LE/ head)

Price of milk yield

(LE/ head)

$\begin{array}{llll}49.560 & 51.024 & 53.070 \quad 54.168\end{array}$

Daily feed cost/ $\mathrm{kg}$ milk yield

(LE)

Daily feed cost $4 \%$ FCM yield (LE)

$\begin{array}{llll}2.332 & 2.465 & 2.174 & 2.072\end{array}$

$\begin{array}{llll}2.421 & 2.532 & 2.192 & 2.100\end{array}$

$\begin{array}{llll}30.301 & 30.065 & 33.843 & 35.464\end{array}$

$\begin{array}{lllll}\text { Net revenue/ kg milk yield } \quad 3.668^{\mathrm{b}} & 3.535^{\mathrm{b}} & 3.826^{\mathrm{a}} & 3.928^{\mathrm{a}}\end{array}$

(LE)

$\begin{array}{lllll}\text { Net revenue/ 4\% FCM yield } & 3.810 & 3.632 & 3.858 & 3.982\end{array}$ (LE)

$\begin{array}{lllll}\text { Economical efficiency } & 1.57 & 1.43 & 1.76 & 1.90\end{array}$

*: a, b and c: Means in the same row with different superscripts are significantly $(\mathbf{P}<\mathbf{0 . 0 5})$ different.

$* *$ Based on the assumption that the price of one ton of berseem hay and rice straw was 1600 and $400 \mathrm{LE}$, respectively. The price of concentrate feed mixture sharing in ration A, B, C and D was 1790, 2000, 1765 and 1717, respectively, while the price of one kg milk was 6 LE.

\section{Rumen Parameters:}

The $\mathrm{pH}, \mathrm{NH}_{3}-\mathrm{N}, \mathrm{VFA}$ 's, Total $-\mathrm{N}$, Protein $-\mathrm{N}$ and NPN concentrations for rumen liquors of animals fed different experimental rations are shown in Table (7). It could be noticed that the differences in $\mathrm{pH}$ values, total VFA's and protein-N concentration among different rumen liquor of experimental animals were not significant, while differences in $\mathrm{NH}_{3}-\mathrm{N}$, Total $-\mathrm{N}$ and NPN concentrations were significant $(\mathrm{P}<0.05)$. The $\mathrm{NH}_{3}-\mathrm{N}$ concentration of rumen liquor of animals fed ration $\mathrm{D}$ was significant $(\mathrm{P}<0.05)$ higher than those fed other rations. On the other hand, rumen liquor of animals fed ration $\mathrm{A}$ recorded significant $(\mathrm{P}<0.05)$ lower in total-N and NPN than those fed other rations. 
The data obtained in Table (7) showed that the $\mathrm{pH}$ values were affected by level and source of both $\mathrm{CP}$ and carbohydrate as mentioned by Johnson and Soltan (1968). Also, VFA's concentrations in rumen liquor were affected by several factors such as DM digestibility, rate of absorption, rumen $\mathrm{pH}$, transportation of the digesta from the rumen to the lower part of the digestive tract and microbial population in the rumen and their activities (Allam et al., 1984). Moreover, increasing in total VFA's concentration might be due to increase digestibility of OM as reported by Arelovich et al. (2000) and Etman et al. (2011). On the other hand, the protein-N and NPN concentration reflected to total $-\mathrm{N}$ concentration. In addition, the fluctuation in $\mathrm{pH}$ values, NH3-N and VFA's concentrations might be attributed to ration composition, feeding type, feeding level, roughage to concentrate ratio and time sampling as reported by Etman et al. (2011).

Table 7. Average some rumen liquor parameters of animals fed different experimental rations

\begin{tabular}{lcccc}
\hline \multirow{2}{*}{ Items } & \multicolumn{4}{c}{ Experimental rations } \\
& A & B & C & D \\
\hline pH value & 6.45 & 6.72 & 6.80 & 6.75 \\
$\mathrm{NH}_{3}-\mathrm{N}(\mathrm{mg} / 100 \mathrm{ml})$ & $11.20^{\mathrm{b}}$ & $12.45^{\mathrm{b}}$ & $12.74^{\mathrm{b}}$ & $14.58^{\mathrm{a}}$ \\
$\mathrm{VFA}^{\prime} \mathrm{s}(\mathrm{mleq} / 100 \mathrm{ml})$ & 11.74 & 11.98 & 12.20 & 12.42 \\
Total -N (mg/ 100 ml) & $152.16^{\mathrm{b}}$ & $160.04^{\mathrm{a}}$ & $158.16^{\mathrm{a}}$ & $162.18^{\mathrm{a}}$ \\
Protein - N (mg/ 100ml) & 98.72 & 100.12 & 98.98 & 102.20 \\
NPN (mg/100 ml) & $53.44^{\mathrm{b}}$ & $59.92^{\mathrm{a}}$ & $59.18^{\mathrm{a}}$ & $59.98^{\mathrm{a}}$ \\
\hline
\end{tabular}

a and b: Means in the same row with different superscripts are significantly $(\mathrm{P}<0.05)$ different.

\section{Some blood parameters:}

The results obtained in Table (8) showed that the differences in blood total protein concentration of animals fed different experimental rations were not significant, showing somewhat higher concentration with animals fed ration $\mathrm{D}$ (containing DDGS), recording 6.96 versus 6.34, 6.52 and $6.54 \mathrm{gm} / 100 \mathrm{ml}$ with animals fed rations $\mathrm{A}, \mathrm{B}$ and $\mathrm{C}$, respectively. On the other hand, the differences in the albumin and globulin concentrations showed higher $(\mathrm{P}<0.05)$ significant between animals fed ration $\mathrm{D}$ and those fed other rations, giving the highest concentration with ration D (containing DDGS). At the same time, the ratio between albumin and globulin among all different treatments were not significant. It could be noticed that higher concentration of total protein and its components such as albumin and globulin with animals fed ration D might be due to improve of nitrogen absorption (Kornegay et al. 1997) and increase CP digestibility (Yousef and Zaki, 2001). Data were agreement with those reported by Kumar et al. (1980) who found a positive correlation between level of protein in ration and serum protein concentration. Also, data were agreement with the finding of Etman et al. (2011) who reported that the concentration of total protein, albumin and globulin tended to increase with increasing DDGS level in rations. Data in Table (8) revealed that the difference in concentrations of AST and ALT as an indicator for liver function were significant $(\mathrm{P}<0.05)$, showing lower concentration with animals fed ration $\mathrm{B}$ than those fed others. However, Boots et al. (1969) reported that the GOT and GPT concentration depends on several factors such as: feeding practices, genetic control, response to stress, age, liver function and body weight. In this respect, results were agreement with those reported by Etman et al. (2011). On the contrary, the differences in concentration of blood creatinin and urea nitrogen as a kidney function were not significant. Also, the ratio between blood urea nitrogen and creatinin were not significant, as shown in Table (8).
Table 8. Average blood parameters of lactating Friesian cows fed different experimental rations.

\begin{tabular}{lcccc}
\hline \multirow{2}{*}{ Items } & \multicolumn{4}{c}{ Experimental rations } \\
\cline { 2 - 5 } & $\mathbf{A}$ & $\mathbf{B}$ & $\mathbf{C}$ & $\mathbf{D}$ \\
\hline Serum protein(gm/100ml): & & & & \\
Total protein & 6.34 & 6.52 & 6.54 & 6.96 \\
Albumin (A) & $4.02^{\mathrm{b}}$ & $4.05^{\mathrm{b}}$ & $4.08^{\mathrm{b}}$ & $4.25^{\mathrm{a}}$ \\
Globulin (G) & $2.32^{\mathrm{b}}$ & $2.47^{\mathrm{b}}$ & $2.46^{\mathrm{b}}$ & $2.71^{\mathrm{a}}$ \\
A/G ratio & 1.73 & 1.64 & 1.66 & 1.57 \\
\hline Liver function (IU/L): & & & & \\
AST & $44.86^{\mathrm{a}}$ & $43.14^{\mathrm{b}}$ & $44.75^{\mathrm{a}}$ & $44.62^{\mathrm{a}}$ \\
ALT & $24.52^{\mathrm{a}}$ & $23.18^{\mathrm{b}}$ & $24.96^{\mathrm{a}}$ & $24.15^{\mathrm{a}}$ \\
\hline Kidney function (mg/dL): & & & & \\
Creatinine & 1.18 & 1.22 & 1.24 & 1.20 \\
BUN & 16.24 & 16.84 & 17.40 & 17.45 \\
BUN/ creatinin & 13.76 & 13.80 & 14.03 & 14.54 \\
\hline AST: Aspartate Amino Tranf & & & &
\end{tabular}

AST: Aspartate Amino Transfers

BUN: Blood urea nitrogen

ALT: Alanin Amino Transfers.

In general, the previous parameter concentration were not affected by source of ration protein, and the data were similar with those reported by Lopez et al. (2010), Etman et al. (2010\& 2011).

\section{CONCLUSION}

Generally, it could be concluded that, using DDGS with rate of $26 \%$ to cover $50 \%$ of total protein of concentrate feed mixture in lactating Friesian rations appeared to better digestibility and feeding value. Moreover, animals fed ration containing DDGS showed higher milk yield, giving the highest net revenue with the lowest feed cost and the best economical efficiency without any adverse effects on rumen or blood parameters.

\section{REFERENCES}

A.O.A.C. (2000). Association of Official Analytical chemists. Official Methods of Analysis Washington, D,C., USA.

Allam, S.M.; A.K. Abou -Raya; E.A. Gihad and T.M. ElBadawy (1984). Nutritional studies by sheep and goats fed $\mathrm{NaOH}$ treated straw. $1^{\text {st }}$ Egyptian-British Conf. Anim. and Poultry Prod., Zagazig Univ. 11-13 Sept., p. 53.

Anderson, J.L.; D.J. Schingoethe,;R.F.Kalscheur, and A.R.Hippen (2006).Evaluation of dried and wet distillers included at two concentrations in diets of lactating dairy cows. J. Dairy Sci.; 89 (8): 3133-42.

Arelovich, H.M.; F.N. Owens; G.W. Horn and J.A. Vizcarra (2000). Effect of supplemented zinc and manganese on ruminal fermentation forage intake and digestion by cattle fed prairie hay and urea. J. Anim. Sci. 78: 2972-2979.

Boots, L.R.; W.L. Cerist,.; D.R. Davis,; E.W. Brum, and T.M. Ludwick, (1969).Effect of age, body weight, stage of gestation and sex on plasma glutamic oxaloaceticand glutamic-pyrovic transaminase activities in inmature Holstein Cattle. J. Dairy Sci. 52, 2: 211 . 
Bremer, V.B.; G.E. Erickson; T.J. Klopfenstein; M.L. Gibson; K.J. Vander Pol and M.A.Greenquist (2005). Feedlot performance of a new distillers by product (Dakota Bran) for finishing cattle. J. Anim. Sci., 83: (Suppl. 1).

Caines, W.L. (1923). Relation between percentage of fat content and yield of milk correction of milk yield for fat content. Agric . Exp. Sta.Bull.,245

Church, D. C. and W. G. Pond. (1982). Feedstuffs for animals. In: Basic Animal Nutrition and Feeding. John Wiley and Sons. NY, USA. E

Duncan, D.B. (1955). Multiple range and Multiple F-test. Biometrics, 11: 1-42.

Eadie, J.M.P.; N. Hobson, and S.O. Mann (1976). A note on some comparisons between the rumen content of barley fed steers and that of young calves fed on high concentrate rations. J. Anim. Prod. 9: 247.

El-Monayer, T.I. (2015). Using new protein sources in feeding ruminants. 2- Using guar korma meal in rations of lactating buffalo cows. J. Animal and Poultry Prod. Mansoura Univ., (8): 537-554.

El-Sayed, H.M.; M.A.El-Ashry, H.M.Metwally, M.Fadel, and M.M. Khorshed, (2002). Effect of chemical and biological treatments of some crop-residues on their nutritive value. 3-Digestion coefficients, rumens and blood serum parameters of goats.Egypt. J. Nutr. And Feed. 5 (1): 55-69.

El-Shinnawy, M.M.; K.E.I. Etman, Gihan, M. El-Moghazy and A.M.El-Shinnawy (2015).Efficancy of different levels of dried distillers grains with solubles as replacement for soybean meal and portion of eh corn in a growing and finishing buffalo calves diet. The $15^{\text {th }}$ Scientific Conference of Animal Nutrition 17-20 Nov., Vol. 18 (2), Special Issue, Hurghada, Egypt.

Etman, K.E.I.; A.M. Zied, T.I. El-Monayer, S.B. Mehany; and A.M.A. Galila (2012). Utilization of new nutritional resources in ruminant feeding 3) Effect of using dried distillers grains with solubles (DDGS) as protein source in rations for lactating Friesian cows. J. Animal and Poultry Prod., Mansoura Univ. Vol. 3 (11): 523-536.

Etman, K.E.I.; A.M.M Zeid, and T.I. El-Monayer (2010).Utilization from new nutritional resources in ruminant feeding: 1) Effect of using dried distillers grains with solubles (DDGS) in rations for fattening Friesian calves. J. Animal and Poultry Prod., Mansura Univ.Vol. 1 (12) 659-669.

Etman, K.E.I.; I.M. Ebtehag Abou Elenin, T.I. ElMonayer, and F.A. El-Sayed (2014a). Using new protein sources in feeding ruminants. 1- Effect of feeding different levels of guar korma as a source of protein on the productive performance of Egyptian buffaloes. J. Animal and Poultry Prod., Mansoura Univ.5 (12): 619-634.

Etman, K.E.I.; T.I. El-Monayer, S.K.Sayed, F.A. El-Sayed and Mona, E. Farag (2014).Some studies on using different levels of dried distillers grains with solubles (DDGS) on animal performance. 1- Effect of feeding different levels of DDGS as a source of energy on sheep performance. J. Animal and Poultry Prod., Mansoura Univ. Vol. 5 (2): 27-41.
Etman, K.E.I.; T.I.El-Monayer A.M.M.Zeid,;I.M. EbtehagAbou-Elenin; and S.K. Sayed (2011).Utilization of new nutritional resources in ruminant feeding: 2) Effect of using dried distillers grains with solubles (DDGS) as protein source in rations for fattening buffalo calves. J. Animal and Poultry Prod., Mansoura univ. Vol. 2 (6): 201-215.

Faichney, G.J. and G.A. White (1997). Formaldehyde treatment of concentrate diets for sheep. 1-Partition of digestion of organic matter and nitrogen between the stomac and intestine. Aust. J. Agric. Res. 28: 1055.

Janicek, B.N.; P.J.Kononoff, A.M. Gehman and P.H. Doane (2008). The effect of feeding dried distillers grains plus soluble on milk production and excretion of urinary purine derivatives. J. Dairy Sci., 91 (9): 3544-53.

Johnson, V.W. and Sutton J.D. (1968). The continuous recording of $\mathrm{pH}$ in the bovin rumen. Br. J. Nutr., 22: 303.

Kelezr, J.M.; P.J.Kononoff; A.M.Gehman; L.O. Tedeschi;K. Karge, and M.I. Gibson (2009).Effect of feeding three types of corn -milling co-products on milk production and ruminal fermentation of lactating Holstein cattle. J. Dairy Sci., 92 (10): 5120-5132.

Kornegay, E.T.;Z. Wany; C.M. Wood; and M.D. Lindemann (1997).Supplemental chromium piolinate: Influence nitrogen balance, dry matter, digestibility and carcass traits in growing finishing pigs. J. Anim. Sci., 75: 1319.

Kumar, N.U.; B.Singh; and D.N. Verma (1980). Effect of different levels of dietary protein and energy on growth of male buffalo calves. Ind. J. Anim. Sci., 51: 513 .

Leupp, J.L.; G.P.Lardy; K.K.Karges; M.L. Gibson; and T.S. Caton (2009).Effect of increasing level of corn distiller dried grains with solubles on intake, digestion and ruminal fermentation in steers fed seventy percent concentrate diets. J. Anim. Sci., 87: 2906.

Lopez, O.C.; R.Bodas; N.Prieto; P.Fruto; S.Andress; and F.J. Giralez (2010). Vinasse added to the concentrate for fattening lambs: Intake, animal performance, and carcass and meat characteristics. J. Anim. Sci., 89: 1153-1162.

May, M. L.; M. J. Quinn; B. E. Depenbusch; C. D. Reinhard;L.Gibson; K.K.Karges;N.A. Cole; and J.S. Drouillard (2009). Dried distillers grains with solubles reduced corn silage level in beet finishing diet. J. Anim. Sci., Vol. 10: 2527.

NRC. (1989). Nutrient Requirements of Domestic Animals. Nutrient Requirements of cattle. National Research Council, National Academy of Science. Washington, D.C., USA.

Reed. J.J.; G.P.Lardy;M.L.Bauer;M. Gibson;' and J.S. Caton (2006).Effect of season and inclusion of corn distiller dried grains with soluble in creeps feed on intake, microbial protein synthesis and efficiency, ruminal fermentation, digestion and performance, North Dekota, J. Anim. Sci., Vol. 84 (8). 
SAS, (1996). Statistical analysis system/ User's Guide Static's Ver, 6-06 $4^{\text {th }}$ ED. SAS Institute Inc., Cary, NC.

Van Keulen, J. and B.A. Young (1977).Evolution of insoluble as a natural marker in ruminant digestibility studies. J. Anim. Sci., 44: 282.

Walter, L.J.; T.A. McAllister; W.Z.Yang; K.A.Beauchemin; M.He; J.J. Mickinon (2012). Comparison of wheat or corn dried distiller grains with souloble on rumen fermentation and nutrient digestibility by feedlot heifers. J. Anim. Sci., 90 (4):
Yousef, H.M. and A.A. Zaki (2001). Effect of barley radical feeding on body weight gain and some physiological parameters of growing Friesian crossbred calves. Egyptian. J. Nutrition and Feeds, 4 (special issue): 465-472.

Zhang, S.Z., G.B. Penner, W.Z. Yang and M. Oba.(2010). Effects of partially replacing barley silage or barley grain with DDGS on rumen fermentation and milk production of lactating dairy cows. J. Dairy Sci.93: 3231-3242. Z 1291-1300.

\section{وتأثير إستخدام النواتج العرضية لتقطير الحبوب المجفةة بالسوائل كمصادر بروتينية جديدة على إنتاج وجودة اللحوم

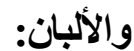 \\ ا ـ إستخدام منتجات تقطير الحبوب بدلاً من كسب القطن أو كسب فول الصبويا في علائق الأبقار الفريزيان الحلابة الصبان

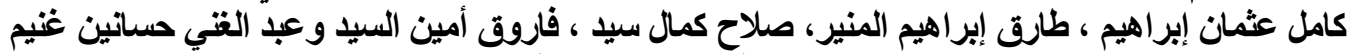

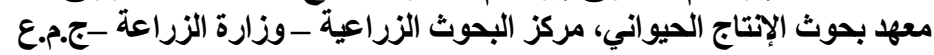

يهدف هذا البحث إلى دراسة تأثير إستخدام منتجات تقطير الحبوب المجفقة بالسو ائل DDGS في علائق أبقار الفريزيان الحلابـة على

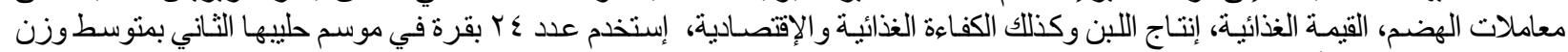

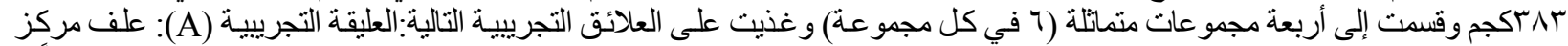

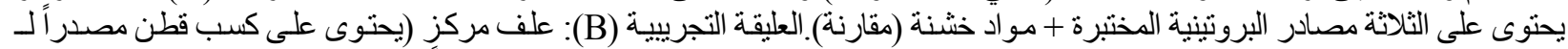

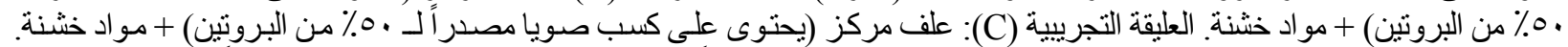

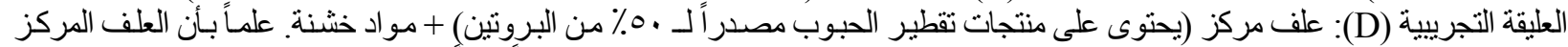

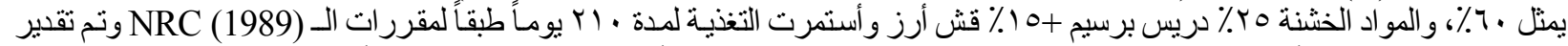

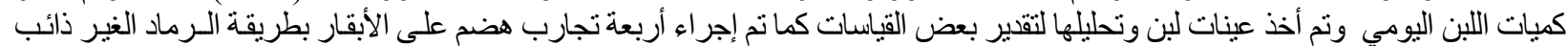

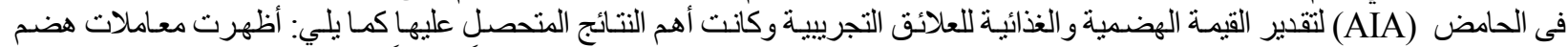

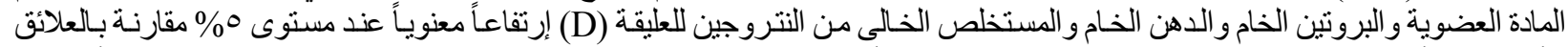

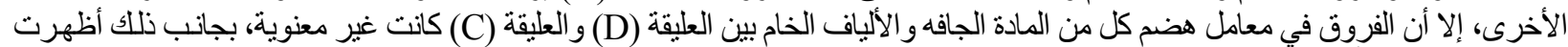

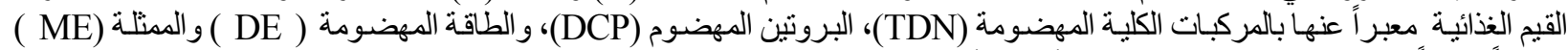

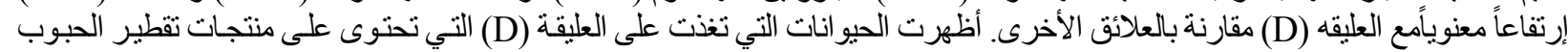

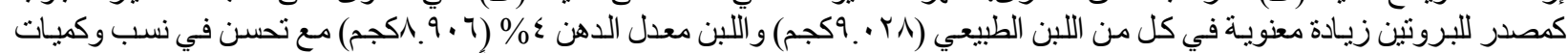

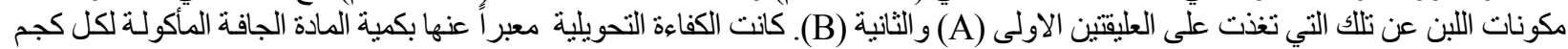

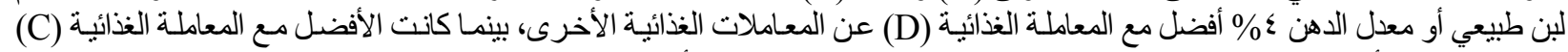

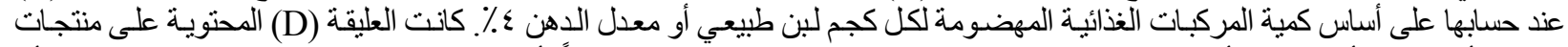

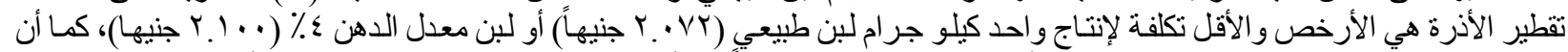

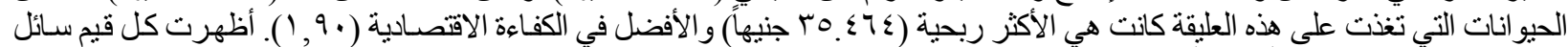

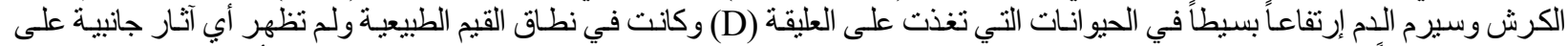

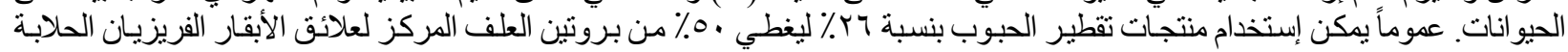

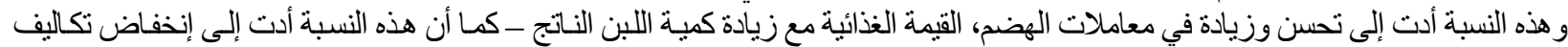
التغذية مع زيادة الربحية و إرتفاع الكفاءة الإنتصادية. 